\title{
Recent Secular Trends in Pubertal Timing: Implications for Evaluation and Diagnosis of Precocious Puberty
}

\author{
Kaspar Sørensen Annette Mouritsen Lise Aksglaede Casper P. Hagen \\ Signe Sloth Mogensen Anders Juul \\ Department of Growth and Reproduction, Rigshospitalet, Faculty of Health Sciences, University of Copenhagen, \\ Copenhagen, Denmark
}

\author{
Key Words \\ Precocious puberty $\cdot$ Pubertal timing $\cdot$ Pubertal \\ examination $\cdot$ Orchidometry $\cdot$ Thelarche
}

\begin{abstract}
The decline in age at puberty in the general population has been paralleled by an increase in the number of girls referred for evaluation of precocious puberty (PP). In 1999, The Lawson Wilkins Pediatric Endocrine Society recommended a lowering of the age limit for evaluation of PP in girls. However, the limited evidence on which these recommendations were based led many experts to question these new suggestions. The emergence of new European pubertal timing data evaluated by robust clinical as well as biochemical markers has broadened our insight on how to interpret the recent pubertal changes. The recent pubertal trends have resulted in a concomitant lowering of the lower limit of normality of the pubertal onset. However, evidence suggests that age at the gonadotropin and sex steroid surges have not changed. Thus, it looks as if an increasing proportion of contemporary early pubertal girls may experience isolated gonadotropinindependent thelarche rather than central PP, which may not be discernible on pubertal examination alone. Thus, the population-based limits of normality should not be directly
\end{abstract}

translated into revision of age limits for evaluation of PP due to the risk of misdiagnosing rapid progressive PP as well as intracranial and other underlying pathology.

Copyright $\odot 2012$ S. Karger AG, Basel

\section{Introduction}

Puberty is an important developmental milestone. It can be considered as a complex sequence of biological events leading to progressive maturation of sexual characteristics ultimately leading to attainment of full reproductive capacity. The timing of puberty has received considerable attention during the past decades due to the associations with risk of breast cancer and cardiovascular disease in adulthood [1].

Until the mid-20th century, a gradual decline in age at menarche has been reported in most industrialized populations [2]. Thereafter, this trend ceased as a result of increased stability in socioeconomic conditions, improved nutrition and hygiene. In the 1990s, two American studies turned our attention towards new secular pubertal trend in both girls and boys [3-7]. Although data from European populations collected in the same period failed to show similar trends $[8,9]$, contemporary studies

\section{KARGER}

Fax +4161306 1234

E-Mail karger@karger.ch

www.karger.com
(C) 2012 S. Karger AG, Basel

$1663-2818 / 12 / 0773-0137 \$ 38.00 / 0$

Accessible online at:

www.karger.com/hrp
Kaspar Sorensen, MD

Department of Growth and Reproduction, GR-5064

Copenhagen University Hospital, Blegdamsvej 9

DK-2100 Copenhagen (Denmark)

E-Mail kaspar.Soerensen@rh.regionh.dk 
now suggest similar drastic changes in European girls $[10,11]$ and to lesser extent in European boys $[9,12]$. In addition, a parallel increase in the number of girls referred for evaluation of precocious puberty (PP) has recently been reported [13].

The repeated American findings supporting an ongoing secular trend towards earlier pubertal timing elicited a lively debate among pediatric endocrinologist concerning the possible implication for the evaluation and diagnosis of PP, and prompted The Lawson Wilkins Pediatric Endocrine Society (LWPES) to recommend a lowering of the age limit for evaluation of PP in girls [14]. However, the limited evidence on which these recommendations were based as well as concerns of overlooking treatable pathological conditions underlying the precocious onset of puberty have led many experts to question these recommendations [15-18]. However, the emergence of new European pubertal timing data evaluated by robust clinical as well as biochemical markers has broadened our insight of how to interpret the recent pubertal changes $[10,12]$.

Genetic factors play a major role in the timing of puberty $[19,20]$. However, the rapid advancement in pubertal timing over the past decades clearly indicates an environmental etiology. The obesity epidemic has received special attention [21, 22]. Although consistent evidence supports that higher adiposity is associated with earlier pubertal maturation in girls $[23,24]$, a similar relationship in boys remains controversial [12, 24, 25]. In addition, changes in fetal nutrition, childhood dietary habits, physical activity and exposure to endocrine disrupting chemicals are other possible candidates that may influence the endogenous endocrine milieu, and therefore potentially affect maturation of the reproductive system [26].

The present mini-review will focus on (1) secular trends in pubertal timing evaluated by clinical and biochemical markers, and (2) implications for the evaluation and proper diagnosis of PP.

\section{Basic Physiology of Puberty}

The activation of the hypothalamic-pituitary-gonadal (HPG) axis is the fundamental primary event for initiation of puberty. The HPG axis is transiently activated in early infancy [27-29] followed by a relative, but not absolute, quiescent period in childhood [30]. The factors responsible for the reactivation of the HPG axis at onset of puberty are still largely unknown, but involve a complex interplay between metabolic, nutritional, and steroidal factors [26].

In girls, it is generally accepted that the appearance of glandular breast tissue (thelarche) is the most reliable initial sign of estrogenic activity, whereas appearance of pubic hair is attributable to a hormonally distinct process, onset of adrenal gland androgen production (adrenarche), which is not directly related to ovarian activation [31]. Visual grading of breast stages is generally uncomplicated in non-obese girls. However, discrimination of actual glandular breast tissue from adipose tissue is extremely difficult in overweight and obese girls due to accumulation of excessive subcutaneous fat mimicking true glandular breast development. Thus, in light of the obesity epidemic, the inherent risk of overclassification of prepubertal girls as being early pubertal needs to be considered. The addition of breast palpation may partly overcome this problem, and is therefore recommended in clinical settings, as well as in clinical research studies.

In boys, a testicular volume of more than $3 \mathrm{ml}$ is generally considered to be the most reliable marker of pubertal onset [32]. Testicular size is most accurately estimated by ultrasonography, but a reliable proxy can be obtained by comparing the testicular size with the size-standardized beans of a Prader orchidometer [33]. Due to the requirement of testicular palpation, orchidometry has seldom been performed in population-based studies, and most of the current data, therefore, rely solely on visual grading of genital development. However, the subtle changes in penile size and scrotal skin texture that become evident with the onset of puberty may be difficult to appreciate, and the interobserver variation is accordingly substantially higher with genital staging than with orchidometry [34].

\section{Secular Trends in Pubertal Markers in Girls}

The timing of normal puberty has changed remarkably over the past centuries. Historical data from Europe have shown a drastic decline in age at menarche from approximately 17 years in the early 19th century to approximately 13 years by the mid-20th century (fig. 1) [35]. Comparable downward trends have been reported from the US during the first half of the 20th century [36]. From the 1960s, the trend in age at menarche seems to have leveled off in both Europe and the US [3, 8, 9, 37], although minor, but statistically significant, decrements of 2.5-4 months have been reported during the past 25 years [10, $11,38]$. 
Fig. 1. Secular trend in age at menarche according to the first year of data collection. Inset shows the past 50 years in which the secular trend in age at menarche seems to have ceased.
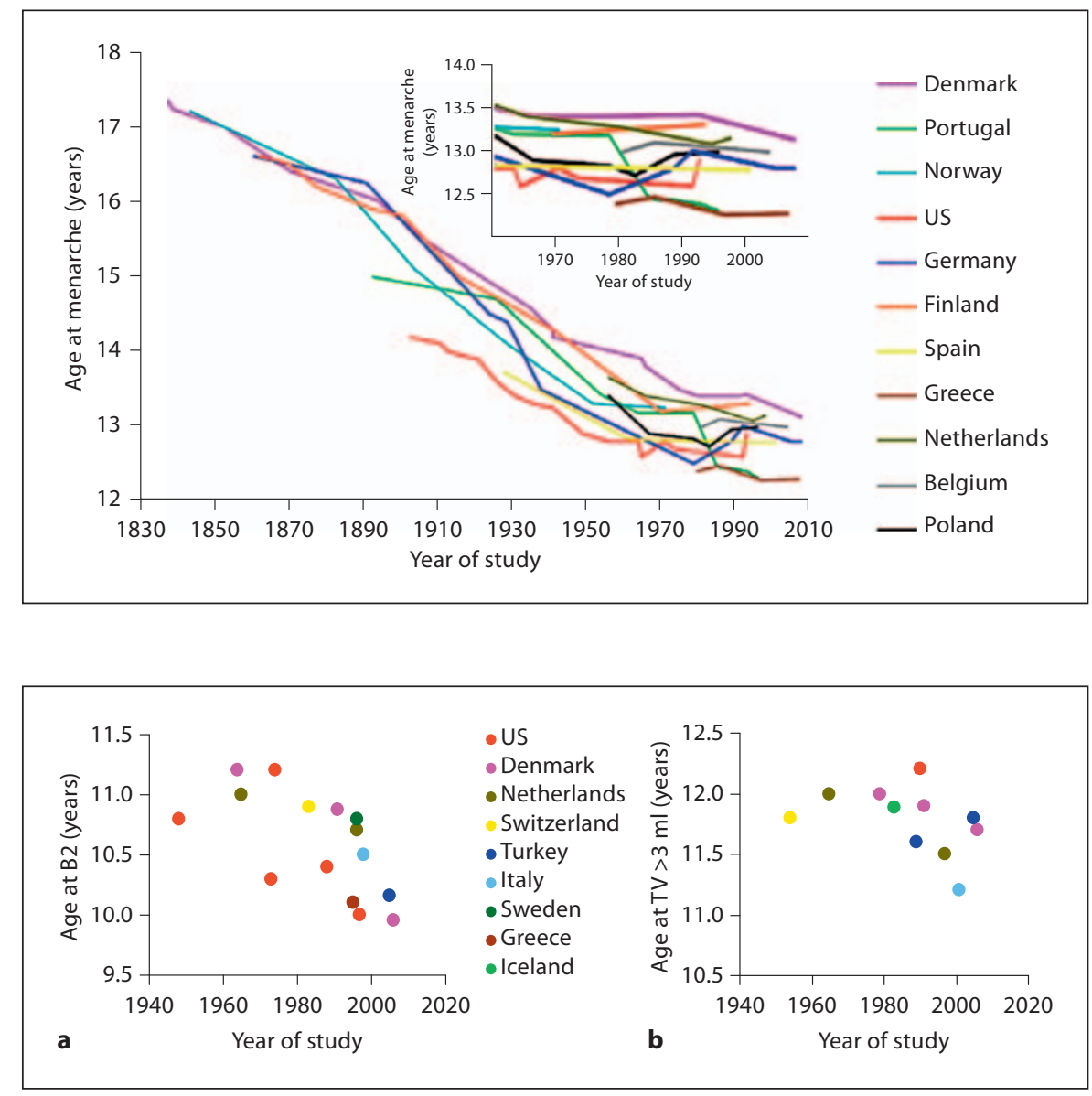

Fig. 2. Secular changes in age at onset of breast stage 2 (B2; a) and of testicular volume of more than $3 \mathrm{ml}$ ( TV $>3 \mathrm{ml}$; b) during the last 60 years. years, $6.7 \%$ of white girls and $27.2 \%$ of African-American girls in the PROS study [3] fulfilled the criteria for evaluation of PP with either breast or pubic hair development. These findings prompted The Lawson Wilkins Pediatric Endocrine Society (LWPES) to re-examine the age limit for evaluation of PP in the US and recommended that evaluation should only be undertaken if clinical signs of puberty were present before the age of 7 years in white girls and before the age of 6 years in African-American girls [14]. Many pediatric endocrinologists have subsequently questioned the evidence on which these recommendations were based and argued that the PROS study was not representative for the general American population $[17,18]$. In addition, it only included girls up to the age of 12 years, and may therefore have missed the late pubertal girls potentially leading to a slight underestimation of the true age at pubertal onset. However, based on the newest US data by Biro et al. [39], the proportion of white and black girls presenting with breast development before the age of 8 years seems to be increasing further 


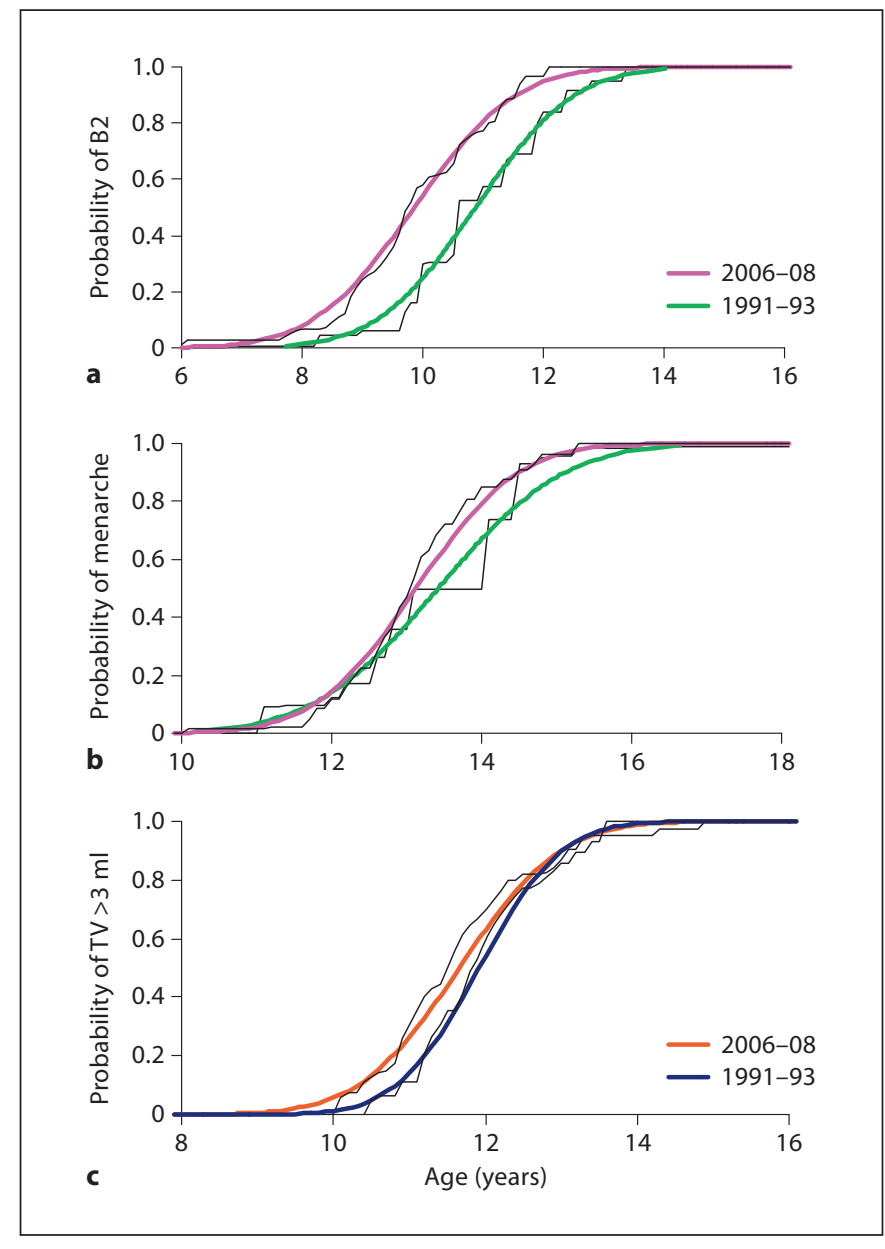

Fig. 3. Data on age at puberty in healthy girls and boys collected in the Copenhagen area in two periods: 1991-1993 and 20062008. Probability of attainment of breast stage B2 (or more) assessed by visual inspection and breast palpation (a), menarche by the status quo (yes/no) method (b), and attainment of testicular volume above $3 \mathrm{ml}$ by use of Prader's orchidometer (c) according to chronological age. Thin black lines represent the raw turn-bull estimates. The 1991-1993 cohort is presented in green and blue and the 2006-2008 cohort in purple and orange in girls and boys, respectively. Modified with permission $[10,12]$.

(10.4 and 23.4\%, respectively), indicating that the secular trends in onset of breast development may have continued since the NHANES III and PROS data were collected in the 1990s.

In Europe, studies from 1990s did not support the American findings of earlier onset of breast development $[8,9]$. However, more recently the Copenhagen Puberty Study reported a 12-month decline in mean age at onset of breast development over a 15 -year period in healthy Danish girls (fig. 3) [10]. Similar age at pubertal onset has recently been reported from other European countries $[40,41]$. This may indicate that the secular trends towards earlier pubertal onset evident in the US during the 1990s may now be evident in Europe with a 15 years' delay. At present, the figures from Europe are not as drastic as those seen in the US, although the most recent studies indicate that approximately $5 \%$ of white girls have onset of breast development before 8 years of age $[11,10,40]$.

As for onset of later pubertal stages, a secular trend analysis between HNANES III and the previous population-based study, the Third National Health Examination Survey (NHES III), did not find evidence for advancement in age at onset of breast stage III-V in either black or white American girls [7]. In contrast, age at onset of breast stages III and IV had declined in parallel to the decline in age at onset of breast development in The Copenhagen Puberty Study [10]. However, the evaluation of these later stages of breast development may be subject to considerable interobserver variation, and compatibility between studies and time periods should therefore be interpreted with caution. Nevertheless, data clearly suggest a secular trend towards earlier onset of breast development, whereas age at menarche has only changed marginally in both American and European girls. Although this may indicate that the pubertal period had lengthened over the past decades, definite conclusion cannot be made at present due to the cross-sectional nature of most population-based studies.

\section{Secular Trends in Pubertal Markers in Boys}

Pubertal timing has not received the same attention in boys as in girls, and consequently fewer and mainly smaller studies, many of which are not population-based, are available. Dating back to the earliest reports from the 1940 s, age at onset of genital development has been consistent around 11.5 years in both American and European studies [32, 42]. In NHANES III, boys had a markedly lower age at onset of genital development [4-6] than previously reported from the US [7, 43-45]. However, due to lack of data on pubertal onset from the previous population-based study (NHES III) [45], some controversies exist on how to interpret the NHANES III findings $[4,5,7$, 46]. The suggested extreme decline in age at male genital development was not supported by a similar secular trend in onset of pubic hair development. In addition, the lack of strict interobserver policies in NHANES III has led many pediatric endocrinologist to speculate if the low age at onset of genital development was a result of erroneous 
classification of prepubertal boys as being in early puberty $[46,47]$. In support of the above-mentioned concerns, a contemporary American study using orchidometry found that age at pubertal onset was compatible with previously American and European studies [43]. Unfortunately, orchidometry was not performed in any of the US population-based studies [32]. In Europe, few populationbased studies are available, but in contrast to the contemporary American studies, some of these have performed orchidometry in addition to genital staging for possible secular trend analysis (fig. 2) [8, 9, 48]. In general, no marked secular trend towards earlier age at pubertal onset in boys was evident from the mid-1960s to the late $1990 \mathrm{~s}$ $[8,9]$, although slight indications have been reported [9]. However, The Copenhagen Puberty Study recently documented a decline of 3 months in age at onset of puberty during a recent 15-year period [12] (fig. 3) evaluated by both genital staging and orchidometry. Thus, pubertal onset may be decreasing in boys, although to a much lesser extent than seen in girls. In addition, the age limit of 9 years classically used to define precious puberty in boys still seems to be valid from these population-based data. In accordance, the LWPES did not find evidence to support a lowering of the diagnostic age limit in boys [14].

As for attainment of later pubertal stages, a secular trend analysis between NHES III and NHANES III did not find persuasive evidence in favor of the existence of earlier age among boys entering genital stages 3-5, although some indications were present in non-Hispanic white boys [7]. In The Copenhagen Puberty Study, onset of later pubertal stages was attained at earlier ages just as yearly increment in testicular volume was greater now compared with 15 years before [12]. However, as most studies on pubertal timing are conducted cross-sectionally, the possible changes in the progression of puberty should be interpreted with caution before they are confirmed by longitudinal studies.

\section{Secular Trends in Reproductive Hormone Levels}

The clinical onset of puberty is preceded by reactivation of the HPG axis leading to increasing circulating levels of the gonadotropins and the sex steroid hormones [49]. Thus, if centrally mediated, one would expect the secular trends in clinical onset of puberty to be paralleled by secular trends towards declining age of the pubertal gonadotropin surge. However, such data have not been available from previous population-based studies. In the Copenhagen Puberty Study, the majority of the partici-

Recent Secular Trends in Pubertal Timing pants had blood samples available for the analyses of gonadotropin and sex steroid levels $[10,12]$. Surprisingly, the marked downward secular trend in age at breast development was not paralleled by an earlier increase in gonadotropin and estradiol levels in this study (fig. 4) [10]. In contrast, lower estradiol levels were found in some of the pubertal age groups [10]. Although evaluation was done solely by single non-stimulated gonadotropin and estradiol levels with the risk of missing true pubertal HPG axis activation during the early stages of puberty in some girls [13], this potential bias would have affected both time periods equally in the Copenhagen Puberty Study. Thus, the lack of secular trends in gonadotropin and estradiol levels indicates that the recent advancement in age at thelarche is not caused by earlier central gonadotropin-dependent gonadal pubertal activation, but rather suggests a gonadotropin-independent phenomenon with possible increased estrogenic bioavailability or sensitivity inducing isolated breast development. This may also provide a plausible explanation for the lack of similar marked secular changes in age at menarche $[3,10,38]$, in that attainment of menarche is dependent on a fully activated HPG axis, the timing of which does not seem to have changed significantly during the last decades. However, the exact gonadotropin-independent mechanisms involved in the isolated earlier thelarche are still unknown. Although the obesity epidemic is most likely involved in the recent pubertal changes in girls [21, 50], advancement in age at puberty has been reported without significant changes in BMI [10]. Thus, other environmental factors that can modify sex steroid bioavailability and sensitivity such as changes in physical fitness [51] and nutrition as well as exposure to endocrine disruption chemicals [52] need to be considered.

In contrast to the findings in girls, the modest secular trend towards earlier onset of puberty in boys was paralleled by a secular increase in age-adjusted LH levels in The Copenhagen Puberty Study (fig. 4) [12]. In addition, these changes seemed to be related to secular changes in BMI. Thus, the earlier timing of pubertal testicular growth seems to be, at least partly, due to an earlier reactivation of the HPG axis possibly driven by changes in body composition. However, the influence of adiposity on pubertal timing is still controversial in boys with obesity associated with both early [25] and late pubertal onset [24]. This disparity may be related to differences in the BMI cutoff used to define obesity as well as the degree of adiposity in the reference groups in that both extremes of the adiposity spectrum may be associated with a relative delay in pubertal timing $[12,24,25]$.

Horm Res Paediatr 2012;77:137-145 
Fig. 4. Reproductive hormone levels according to chronological age in 1,276 healthy girls and 965 healthy boys collected in the Copenhagen area in two periods: 1991-1993 and 2006-2008. LH and estradiol levels are presented in girls, and LH and testosterone in boys. Black lines represent the median, 2.5th and 97.5th percentiles. The 1991-1993 cohort is presented in green and blue, and the 2006-2008 cohort in purple and orange in girls and boys, respectively. Modified with permission [10, $12]$.

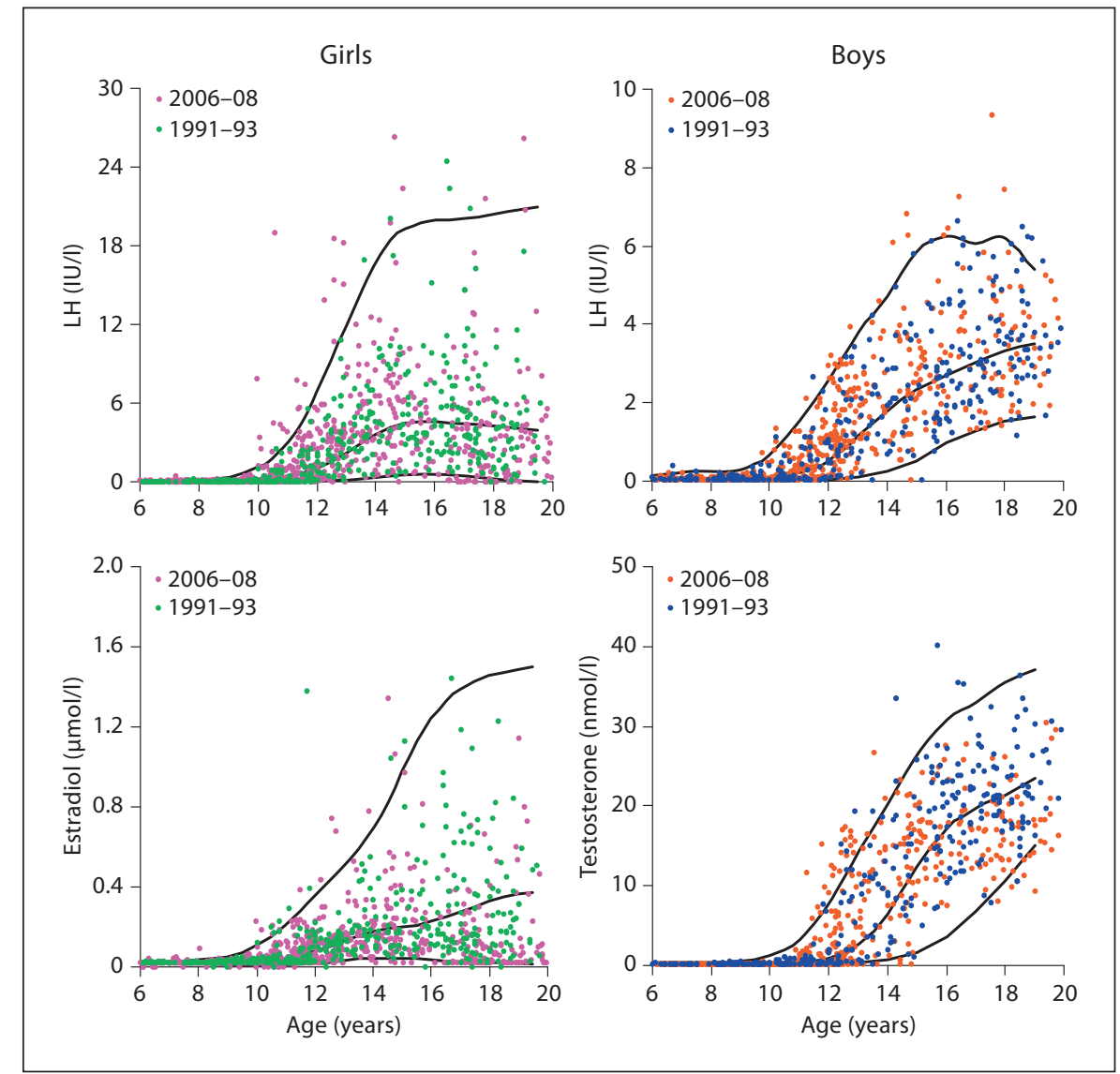

\section{Precocious Puberty}

In girls, $\mathrm{PP}$ is defined as attainment of breast or pubic hair development before the age of 8 years, whereas attainment of genital development, pubic hair development or testicular enlargement of more than $3 \mathrm{ml}$ before the age of 9 years defines PP in boys. In around $90 \%$ of cases in published series $[10,13,53]$, the precocious onset of puberty is centrally mediated by an early reactivation of HPG axis, termed central PP (CPP). In addition to advanced pubertal development, patients with CPP present with growth acceleration, advanced skeletal maturation and elevated gonadotropins during GnRH testing [54]. Although CPP is idiopathic in the majority of girls, 10$20 \%$ of girls and the majority of boys have an underlying organic etiology. In most of these cases, CPP results from pathology within the hypothalamus [55], and brain MRI is therefore generally indicated as part of the routine workup in all patients with CPP.

The prevalence of $\mathrm{PP}$ is about 10 times higher in girls than in boys with an estimated register-based population prevalence in Denmark of approximately $0.2 \%$ in girls and below $0.05 \%$ in boys [56]. However, the secular trends towards earlier pubertal timing in the general population have been paralleled by an increase in the prevalence and incidence of PP in girls (fig. 5) [13]. Although the incidence of gonadotropin-dependent PP is increasing, the sudden increase in all variants of precocious pubertal disorders during the recent decade may be an indication that a greater proportion of early pubertal girls get medical attention than previously. Thus, higher referral rates rather than a true increase in these conditions may play a substantial role in the recently observed trend in PP.

\section{Definition of Pubertal Precocity - Is It Time for a Redefinition?}

The age limits for the diagnosis of PP is classically defined by the lower limit of the $95 \%$ prediction interval (equal to $-2 \mathrm{SD}$ or the 3 rd percentile) based on the distribution of ages at normal puberty for a given population. Importantly, the recent decline in mean age at pubertal onset has resulted in a parallel decline in the lower age 
limit of normality. In girls, but not boys, the 3rd percentile is now far lower than the diagnostic age limit of pubertal precocity defined by the classical work by Marshall and Tanner from the late 1960s [42, 57]. This fact has opened a lively debate among pediatric endocrinologist concerning the necessity of a revision of the age limit for what is considered pubertal precocity requiring further diagnostic evaluation. Although the great majority of recent data consistently indicate that age at pubertal onset is becoming earlier in both Europe $[10,11]$ and the US [3, 6], extrapolation from these population-based findings to redefine the age limit for evaluation of PP may not be appropriate. If the recent secular trends in puberty are driven primarily by an increase in isolated gonadotropin-independent thelarche, lowering of the age limit for evaluation of PP will overlook some girls with true rapid progressive PP from the age of 6 or 7 years leading, if untreated, to menarche by age 8 or 9 , which by populationbased standards will be 1-2 years below the 3rd percentile for normal-timed menarche in both black and white girls.

Another point of concern for a lowering of the age limit for evaluation of PP in girls addressed by many pediatric endocrinologists is the possible misdiagnosis of potentially treatable underlying pathology. In the wake of the LWPES recommendations, several independent groups have undertaken retrospective evaluations of pathology in girls with CPP with pubertal onset after the age of 6 years. The general conclusion from these studies is that implementation of the LWPES recommendations will lead to misdiagnosis of CNS abnormalities in 2-30\% of the girls, some of whom needing surgery and chemotherapy $[15,53,58,59]$. In addition to intracranial pathology, Midyett et al. [16] reported that $12 \%$ of the girls evaluated for PP with pubertal onset after the age of 6 years manifested pathologic endocrine conditions. However, two thirds of these patients presented with hyperinsulinemia that, although girls with CPP may have an increased risk of insulin resistance [60], could be a normal finding considering the high obesity prevalence (45\%) in that cohort. Thus, $5-10 \%$ of girls with CPP may be misdiagnosed if the age limit for evaluation is lowered according to the LWPES recommendations.

Altogether, the cutoff values for ages at which diagnostic evaluation is needed should not be lowered at present, as this would result in a failure to identify children with rapid progressive $\mathrm{PP}$ as well as failure to detect underlying pathology that would respond to early intervention. The criteria for evaluation of PP should rely on additional evaluation of pubertal progression, skeletal maturation or growth tempo, rather than simply lowering the age

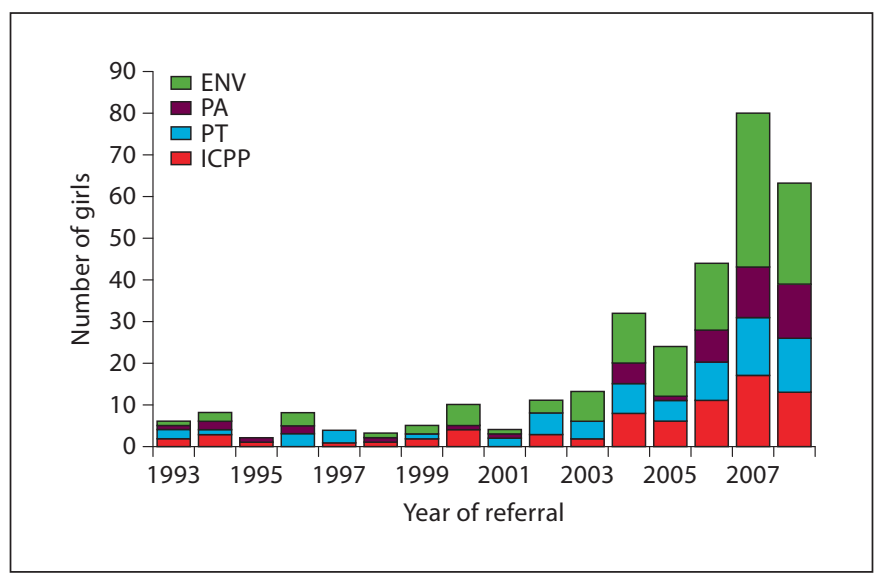

Fig. 5. Number of girls per year diagnosed with early normal puberty $(\mathrm{ENV})$, premature adrenarche (PA), premature thelarche (PT), and idiopathic CPP (ICPP) according to year of referral (1993-2008) in a single tertiary pediatric endocrine center. Reproduced with permission [13].

limit for referral based solely on trends in age at breast development in the general population.

\section{Conclusion}

The trend towards earlier mean age at onset of breast development in girls is accompanied by a downward shift in the entire age distribution at pubertal onset, resulting in a concomitant lowering of the lower limit of normality of breast development. However, these findings are based on population-based studies of healthy girls who did not show associated secular trends in timing of the pubertal LH and estradiol surges. Thus, it appears as if we may primarily be witnessing a phenomenon of isolated gonadotropin-independent thelarche among our contemporary girls. It remains to be seen whether or not this earlier breast development will advance the entire sequence of sexual maturation processes, and if it will have possible long-term side effects in the majority of early maturing girls, or only in the small subset of those with rapid progressive pubertal development leading to early menarche. Due to the risk of overlooking rapid progressive PP as well as the risk of misdiagnosing intracranial and other underlying pathology, we do not believe that the populationbased limits of normality should be translated into revision of age limits at which girls with PP should be referred for diagnostic workup including brain MRI. 


\section{References}

1 Golub MS, Collman GW, Foster PM, Kimmel CA, Rajpert-De Meyts E, Reiter EO, Sharpe RM, Skakkebaek NE, Toppari J: Public health implications of altered puberty timing. Pediatrics 2008;121(suppl 3):S218S230.

-2 Euling SY, Selevan SG, Pescovitz OH, Skakkebaek NE: Role of environmental factors in the timing of puberty. Pediatrics 2008; 121(suppl 3):S167-S171.

3 Herman-Giddens ME, Slora EJ, Wasserman RC, Bourdony CJ, Bhapkar MV, Koch GG, Hasemeier CM: Secondary sexual characteristics and menses in young girls seen in office practice: a study from the Pediatric Research in Office Settings network. Pediatrics 1997; 99:505-512.

4 Herman-Giddens ME, Wang L, Koch G: Secondary sexual characteristics in boys: estimates from the national health and nutrition examination survey III, 1988-1994. Arch Pediatr Adolesc Med 2001;155:1022-1028.

5 Karpati AM, Rubin CH, Kieszak SM, Marcus M, Troiano RP: Stature and pubertal stage assessment in American boys: the 1988-1994 Third National Health and Nutrition Examination Survey. J Adolesc Health 2002;30: 205-212.

-6 Sun SS, Schubert CM, Chumlea WC, Roche AF, Kulin HE, Lee PA, Himes JH, Ryan AS: National estimates of the timing of sexual maturation and racial differences among US children. Pediatrics 2002;110:911-919.

-7 Sun SS, Schubert CM, Liang R, Roche AF, Kulin HE, Lee PA, Himes JH, Chumlea WC: Is sexual maturity occurring earlier among U.S. children? J Adolesc Health 2005;37:345355.

8 Juul A, Teilmann G, Scheike T, Hertel NT, Holm K, Laursen EM, Main KM, Skakkebaek NE: Pubertal development in Danish children: comparison of recent European and US data. Int J Androl 2006;29:247-255.

$\checkmark 9$ Mul D, Fredriks AM, van BS, Oostdijk W, Verloove-Vanhorick SP, Wit JM: Pubertal development in The Netherlands 1965-1997. Pediatr Res 2001;50:479-486.

10 Aksglaede L, Sorensen K, Petersen JH, Skakkebaek NE, Juul A: Recent decline in age at breast development: the Copenhagen Puberty Study. Pediatrics 2009;123:e932-e939.

-11 Rubin C, Maisonet M, Kieszak S, Monteilh C, Holmes A, Flanders D, Heron J, Golding J, McGeehin M, Marcus M: Timing of maturation and predictors of menarche in girls enrolled in a contemporary British cohort. Paediatr Perinat Epidemiol 2009;23:492504.

-12 Sorensen K, Aksglaede L, Petersen JH, Juul A: Recent changes in pubertal timing in healthy Danish boys: associations with body mass index. J Clin Endocrinol Metab 2010; 95:263-270.

13 Mogensen SS, Aksglaede L, Mouritsen A, Sorensen K, Main KM, Gideon P, Juul A: Diag- nostic work-up of 449 consecutive girls who were referred to be evaluated for precocious puberty. J Clin Endocrinol Metab 2011;96: 1393-1401.

14 Kaplowitz PB, Oberfield SE: Reexamination of the age limit for defining when puberty is precocious in girls in the United States: implications for evaluation and treatment. Drug and Therapeutics and Executive Committees of the Lawson Wilkins Pediatric Endocrine Society. Pediatrics 1999;104:936941.

15 Chalumeau M, Hadjiathanasiou CG, Ng SM, Cassio A, Mul D, Cisternino M, Partsch CJ, Theodoridis C, Didi M, Cacciari E, Oostdijk W, Borghesi A, Sippell WG, Breart G, Brauner R: Selecting girls with precocious puberty for brain imaging: validation of European evidence-based diagnosis rule. J Pediatr 2003; 143:445-450.

16 Midyett LK, Moore WV, Jacobson JD: Are pubertal changes in girls before age 8 benign? Pediatrics 2003;111:47-51.

17 Rosenfield RL, Bachrach LK, Chernausek SD, Gertner JM, Gottschalk M, Hardin DS, Pescovitz OH, Saenger P: Current age of onset of puberty. Pediatrics 2000;106:622-623.

18 Viner R: Splitting hairs. Arch Dis Child 2002;86:8-10.

19 Elks CE, Perry JR, Sulem P, Chasman DI, et al: Thirty new loci for age at menarche identified by a meta-analysis of genome-wide association studies. Nat Genet 2010;42:10771085.

20 Kaprio J, Rimpela A, Winter T, Viken RJ, Rimpela M, Rose RJ: Common genetic influences on BMI and age at menarche. Hum Biol 1995;67:739-753.

21 Kaplowitz PB: Link between body fat and the timing of puberty. Pediatrics 2008;121(suppl 3):S208-S217.

22 Ong KK, Ahmed ML, Dunger DB: Lessons from large population studies on timing and tempo of puberty (secular trends and relation to body size): the European trend. Mol Cell Endocrinol 2006;254-255:8-12.

23 Kaplowitz PB, Slora EJ, Wasserman RC, Pedlow SE, Herman-Giddens ME: Earlier onset of puberty in girls: relation to increased body mass index and race. Pediatrics 2001;108: 347-353.

24 Wang Y: Is obesity associated with early sexual maturation? A comparison of the association in American boys versus girls. Pediatrics 2002;110:903-910.

25 Ribeiro J, Santos P, Duarte J, Mota J: Association between overweight and early sexual maturation in Portuguese boys and girls. Ann Hum Biol 2006;33:55-63.

26 Parent AS, Teilmann G, Juul A, Skakkebaek NE, Toppari J, Bourguignon JP: The timing of normal puberty and the age limits of sexual precocity: variations around the world, secular trends, and changes after migration. Endocr Rev 2003;24:668-693.
27 Aksglaede L, Sorensen K, Boas M, Mouritsen A, Hagen CP, Jensen RB, Petersen JH, Linneberg A, Andersson AM, Main KM, Skakkebaek NE, Juul A: Changes in anti-Mullerian hormone (AMH) throughout the life span: a population-based study of 1027 healthy males from birth (cord blood) to the age of 69 years. J Clin Endocrinol Metab 2010;95:5357-5364.

28 Chellakooty M, Schmidt IM, Haavisto AM, Boisen KA, Damgaard IN, Mau C, Petersen JH, Juul A, Skakkebaek NE, Main KM: Inhibin A, inhibin B, follicle-stimulating hormone, luteinizing hormone, estradiol, and sex hormone-binding globulin levels in 473 healthy infant girls. J Clin Endocrinol Metab 2003;88:3515-3520.

29 Hagen CP, Aksglaede L, Sorensen K, Main KM, Boas M, Cleemann L, Holm K, Gravholt $\mathrm{CH}$, Andersson AM, Pedersen AT, Petersen JH, Linneberg A, Kjaergaard S, Juul A: Serum levels of anti-Mullerian hormone as a marker of ovarian function in 926 healthy females from birth to adulthood and in 172 Turner syndrome patients. J Clin Endocrinol Metab 2010;95:5003-5010.

30 Hagen CP, Main KM, Kjaergaard S, Juul A: $\mathrm{FSH}, \mathrm{LH}$, inhibin $\mathrm{B}$ and estradiol levels in Turner syndrome depend on age and karyotype: longitudinal study of 70 Turner girls with or without spontaneous puberty. Hum Reprod 2010;25:3134-3141.

- 31 Palmert MR, Hayden DL, Mansfield MJ, Crigler JF Jr, Crowley WF Jr, Chandler DW, Boepple PA: The longitudinal study of adrenal maturation during gonadal suppression: evidence that adrenarche is a gradual process. J Clin Endocrinol Metab 2001;86: 4536-4542.

- 32 Euling SY, Herman-Giddens ME, Lee PA, Selevan SG, Juul A, Sorensen TI, Dunkel L, Himes JH, Teilmann G, Swan SH: Examination of US puberty-timing data from 1940 to 1994 for secular trends: panel findings. Pediatrics 2008;121(suppl 3):S172-S191.

-33 Zachmann M, Prader A, Kind HP, Hafliger $\mathrm{H}$, Budliger $\mathrm{H}$ : Testicular volume during adolescence. Cross-sectional and longitudinal studies. Helv Paediatr Acta 1974;29:61-72.

- 34 Slora EJ, Bocian AB, Herman-Giddens ME, Harris DL, Pedlow SE, Dowshen SA, Wasserman RC: Assessing inter-rater reliability (IRR) of Tanner staging and orchidometer use with boys: a study from PROS. J Pediatr Endocrinol Metab 2009;22:291-299.

35 Tanner JM: Trend towards earlier menarche in London, Olso, Copenhagen, the Netherlands and Hungary. Nature 1973;243:95-96.

36 Wyshak G, Frisch RE: Evidence for a secular trend in age of menarche. N Engl J Med 1982; 306:1033-1035.

37 Chumlea WC, Schubert CM, Roche AF, Kulin HE, Lee PA, Himes JH, Sun SS: Age at menarche and racial comparisons in US girls. Pediatrics 2003;111:110-113. 
-38 Anderson SE, Dallal GE, Must A: Relative weight and race influence average age at menarche: results from two nationally representative surveys of US girls studied 25 years apart. Pediatrics 2003;111:844-850.

39 Biro FM, Galvez MP, Greenspan LC, Succop PA, Vangeepuram N, Pinney SM, Teitelbaum S, Windham GC, Kushi LH, Wolff MS: Pubertal assessment method and baseline characteristics in a mixed longitudinal study of girls. Pediatrics 2010;126:e583-e590.

40 Papadimitriou A, Pantsiotou S, Douros K, Papadimitriou DT, Nicolaidou P, Fretzayas A: Timing of pubertal onset in girls: evidence for non-Gaussian distribution. J Clin Endocrinol Metab 2008;93:4422-4425.

-41 Semiz S, Kurt F, Kurt DT, Zencir M, Sevinc O: Pubertal development of Turkish children. J Pediatr Endocrinol Metab 2008;21: 951-961.

42 Marshall WA, Tanner JM: Variations in the pattern of pubertal changes in boys. Arch Dis Child 1970;45:13-23.

-43 Biro FM, Lucky AW, Huster GA, Morrison JA: Pubertal staging in boys. J Pediatr 1995; 127:100-102.

44 Foster TA, Voors AW, Webber LS, Frerichs RR, Berenson GS: Anthropometric and maturation measurements of children, ages 5 to 14 years, in a biracial community - the Bogalusa Heart Study. Am J Clin Nutr 1977;30 582-591.

-45 Harlan WR, Grillo GP, Cornoni-Huntley J, Leaverton PE: Secondary sex characteristics of boys 12 to 17 years of age: the U.S. Health Examination Survey. J Pediatr 1979;95:293297.

46 Herman-Giddens ME: Recent data on pubertal milestones in United States children: the secular trend toward earlier development. Int J Androl 2006;29:241-246.
47 Walvoord EC: The timing of puberty: is it changing? Does it matter? J Adolesc Health 2010; 47:433-439.

48 Sorensen K, Nielsen J, Busch P, HamborgPetersen B, Hansen E, Lassen LB, Nielsen K, Poulsen JP, Rossen K, Schaap SK, Taudorf K, Thelle T, Vestermark S, Vrang C: Measurement of testicular volume with Prader's orchiometer in 1,389 boys 5-15 1/2 years old. Ugeskr Laeger 1979;141:915-918.

49 Albertsson-Wikland K, Rosberg S, Lannering B, Dunkel L, Selstam G, Norjavaara E: Twenty-four-hour profiles of luteinizing hormone, follicle-stimulating hormone, testosterone, and estradiol levels: a semilongitudinal study throughout puberty in healthy boys. J Clin Endocrinol Metab 1997;82:541549.

50 Davison KK, Susman EJ, Birch LL: Percent body fat at age 5 predicts earlier pubertal development among girls at age 9. Pediatrics 2003;111:815-821.

51 Sorensen K, Aksglaede L, Munch-Andersen T, Aachmann-Andersen NJ, Petersen JH, Hilsted L, Helge JW, Juul A: Sex hormonebinding globulin levels predict insulin sensitivity, disposition index, and cardiovascular risk during puberty. Diabetes Care 2009;32: 909-914.

52 Buck Louis GM, Gray LE Jr, Marcus M, Ojeda SR, Pescovitz OH, Witchel SF, Sippell W, Abbott DH, Soto A, Tyl RW, Bourguignon JP, Skakkebaek NE, Swan SH, Golub MS, Wabitsch M, Toppari J, Euling SY: Environmental factors and puberty timing: expert panel research needs. Pediatrics 2008; 121(suppl 3):S192-S207.
53 Cisternino M, Arrigo T, Pasquino AM, Tinelli C, Antoniazzi F, Beduschi L, Bindi G, Borrelli P, De S, V, Farello G, Galluzzi F, Gargantini L, Lo PD, Sposito M, Tato L: Etiology and age incidence of precocious puberty in girls: a multicentric study. J Pediatr Endocrinol Metab 2000;13(suppl 1):695-701.

- 54 Carel JC, Eugster EA, Rogol A, Ghizzoni L, et al: Consensus statement on the use of gonadotropin-releasing hormone analogs in children. Pediatrics 2009;123:e752-e762.

55 Nathan BM, Palmert MR: Regulation and disorders of pubertal timing. Endocrinol Metab Clin North Am 2005;34:617-641, ix.

56 Teilmann G, Pedersen CB, Jensen TK, Skakkebaek NE, Juul A: Prevalence and incidence of precocious pubertal development in Denmark: an epidemiologic study based on national registries. Pediatrics 2005;116:13231328.

57 Marshall WA, Tanner JM: Variations in pattern of pubertal changes in girls. Arch Dis Child 1969;44:291-303.

58 Mogensen SS, Aksglaede L, Mouritsen A, Sorensen K, Main KM, Gideon P, Juul A: Pathological and incidental findings on brain MRI in a single-center study of 229 consecutive girls with early or precocious puberty. PLoS One, DOI:10.1371/journal.pone. 0029829.

59 Ng SM, Kumar Y, Cody D, Smith CS, Didi M: Cranial MRI scans are indicated in all girls with central precocious puberty. Arch Dis Child 2003;88:414-418.

60 Sorensen K, Mouritsen A, Mogensen SS, Aksglaede L, Juul A: Insulin sensitivity and lipid profiles in girls with central precocious puberty before and during gonadal suppression. J Clin Endocrinol Metab 2010;95:37363744. 